\title{
Studies on Increasing Sewage Load in River Yamuna and Its Impact on Some Common Microbes
}

\author{
P. K. Agrawal \\ Department of Zoology, B.S.A. College, Mathura, U.P. (India)
}

\begin{abstract}
River Yamuna at Mathura (U.P.) is badly polluted with sewage and garbage. Being historical and religious city, millions of pilgrims come every year and take bath in the river. This poses a great problem to river's ecology and sustainability. A study was carried out to assess pollution load in the river in different months and its impact on population size of some aquatic microbes. The key indicators of sewage waste load were Coliform count (MPN), BOD, sulphates, phosphates and ammonia. The susceptible microbes that were analysed included Spirogyra sp., Stylonychia sp., Vorticella sp. and species of Euglena. The study revealed that the river has a deplorable level of organic pollutants. The condition becomes worst in summers, when the amount of water in the river is scanty. The population of Coliform bacteria and Spirogyra was found very high in areas where organic pollutants were very high in amount. But other organisms like, Stylonychia spp. Vorticella spp. and Euglena exhibited a severe decline in the population count. This clearly indicated the imbalance in river ecology.
\end{abstract}

Keywords: Pollutants, BOD, Coliform bacteria, Sewage waste, Ecological balance

\section{Introduction}

River Yamuna is an ancient and religious river of India. It originates from Yamunotri in the Himalayan region (Uttaranchal), flows through western and southern Uttar Pradesh and finally drains into the holy Ganga River at Allahabad. During its great course, it also flows through District Mathura (in western U.P.) Mathura was selected as study area as it is considered to be a historical and sacred place, being the birth - place of Lord Krishna. Millions of pilgrims visit Mathura every year and take bath in the holy river Yamuna. The sewage along with the garbage is disposed off either directly or indirectly into the Yamuna, through a number of wide drains and results in heavy water pollution. Further, Mathura is a growing industrial hub. A large number of cotton printing industries and silver vibrators are working here. Their effluents are being mixed directly in the river, creating a huge ecological stress. Due to severe river pollution, the life of bath takers, live stock and aquatic organisms is being sacrificed (Agrawal et al, 2000). In the present study, assessment of pollution load in river Yamuna and simultaneous fluctuations in the population count of some aquatic microbes was carried out.

\section{Selection of sampling sites}

\section{Materials And Methods}

Three sampling sites were selected - a. Site A (upstream), b. Site B (Middle) and c. Site C (downstream). Site A is located near AIR station. Site B passes through the middle of the city, while site is located near Gokul barrage. The sites were selected to compare the entry and exit loads so that the pollutant addition from the city, could be assessed.

\section{Sampling}

Water sample of river Yamuna was taken on $10^{\text {th }}$ of every month (between 7.30 A.M. to 8.30 A.M.). For BOD, the sample was taken in BOD bottles. Parameters like pH, BOD, ammonia, chlorides and sulphates were tested in the laboratory according to standard methods, prescribed by APHA (1989). Some common microbes, present in river water, were also considered as test organisms. These included Coliform bacteria, species of Spirogyra, Stylonychia, Vorticella, and Euglena.. The water sample for determining the population of these organisms was taken separately in 1 litre glass bottles. Samples were preserved at $4^{\circ} \mathrm{C}$ in $4-5 \%$ buffered formalin solution.

\section{Population assessment}

The population of Coliform bacteria was determined by MPN technique. For other organisms, microscopical counting method was used. The sample was concentrated using planktonic nets of different sizes and was then stored in a closed and labelled glass vials. It was mixed properly by thorough shaking and $0.5 \mathrm{ml}$ of the sample was pipetted with a fractional pipette on a clean glass slide. The slide was examined microscopically. Counting and enumeration was done with the help of an occular micrometer. The entire procedure was repeated thrice for each sample and then averages were noted for more reliable results. 


\section{Results}

The monthly observations for physico-chemical parameters and for population count have been shown in following table.

\begin{tabular}{|c|c|c|c|c|c|c|c|c|c|c|c|c|c|}
\hline Parameters/ Microbes & Site & Jan & Feb & Mar & Apr & May & Jun & Jul & Aug & Sep & Oct & Nov & Dec \\
\hline \multirow{3}{*}{$\mathrm{pH}$} & A & 7.8 & 7.9 & 7.5 & 8.2 & 8.5 & 8.5 & 8.6 & 8.2 & 8.3 & 7.9 & 8.0 & 7.6 \\
\hline & $\mathrm{B}$ & 7.6 & 7.8 & 7.2 & 8.1 & 8.6 & 8.2 & 8.4 & 8.1 & 8.1 & 8.0 & 8.1 & 7.8 \\
\hline & $\mathrm{C}$ & 8.0 & 8.1 & 7.9 & 8.3 & 8.5 & 8.8 & 8.8 & 8.4 & 8.0 & 8.1 & 7.8 & 8.2 \\
\hline \multirow{3}{*}{$\mathrm{BOD}(\mathrm{mg} / \mathrm{L})$} & $\mathrm{A}$ & 41 & 58 & 63 & 81 & 101 & 115 & 105 & 95 & 78 & 69 & 54 & 44 \\
\hline & $\mathrm{B}$ & 58 & 64 & 69 & 91 & 118 & 126 & 119 & 108 & 89 & 74 & 67 & 57 \\
\hline & $\mathrm{C}$ & 46 & 59 & 67 & 89 & 98 & 110 & 108 & 98 & 83 & 62 & 58 & 51 \\
\hline \multirow{3}{*}{$\begin{array}{l}\text { Ammonia contents } \\
(\mathrm{mg} / \mathrm{L})\end{array}$} & $\mathrm{A}$ & 0.29 & 0.38 & 0.31 & 0.45 & 0.69 & 0.85 & 0.81 & 0.83 & 0.69 & 0.52 & 0.49 & 0.33 \\
\hline & $\mathrm{B}$ & 0.38 & 0.51 & 0.65 & 0.68 & 0.79 & 0.96 & 0.87 & 0.78 & 0.79 & 0.65 & 0.47 & 0.42 \\
\hline & $\mathrm{C}$ & 0.34 & 0.41 & 0.58 & 0.69 & 0.72 & 0.95 & 0.92 & 0.89 & 0.75 & 0.66 & 0.41 & 0.39 \\
\hline \multirow{3}{*}{$\begin{array}{l}\text { Phosphate contents } \\
\text { (mg/L) }\end{array}$} & $\mathrm{A}$ & 3.5 & 3.8 & 4.1 & 5.8 & 5.9 & 7.5 & 8.1 & 7.1 & 6.7 & 5.8 & 6.1 & 5.2 \\
\hline & $\mathrm{B}$ & 3.8 & 5.8 & 7.3 & 6.9 & 7.9 & 8.5 & 9.6 & 7.8 & 5.9 & 7.4 & 6.9 & 4.8 \\
\hline & $\mathrm{C}$ & 4.9 & 5.4 & 6.7 & 5.8 & 8.9 & 8.2 & 9.1 & 6.9 & 78 & 5.6 & 5.0 & 4.2 \\
\hline \multirow{3}{*}{ Sulphates (mg/L) } & $\mathrm{A}$ & 562 & 630 & 498 & 580 & 770 & 861 & 814 & 778 & 714 & 681 & 701 & 645 \\
\hline & $\mathrm{B}$ & 603 & 595 & 641 & 650 & 715 & 987 & 924 & 828 & 721 & 737 & 740 & 680 \\
\hline & $\mathrm{C}$ & 587 & 605 & 584 & 619 & 709 & 847 & 907 & 837 & 747 & 709 & 685 & 621 \\
\hline \multirow{3}{*}{$\begin{array}{l}\text { Total Coliform } \\
\text { (MPN) x } 1000\end{array}$} & $\mathrm{~A}$ & 19.5 & 18.6 & 22.4 & 24.5 & 28.4 & 31.5 & 35.2 & 29.5 & 25.4 & 22.6 & 24.9 & 19.1 \\
\hline & $\mathrm{B}$ & 24.1 & 22.8 & 25.6 & 27.4 & 32.5 & 36.8 & 30.5 & 30.8 & 27.4 & 26.5 & 27.6 & 25.8 \\
\hline & $\mathrm{C}$ & 22.5 & 23.5 & 25.8 & 29.4 & 31.4 & 34.1 & 29.5 & 31.5 & 28.1 & 25.4 & 22.4 & 20.8 \\
\hline \multirow{3}{*}{ Spirogyra spp. } & $\mathrm{A}$ & 45 & 61 & 49 & 77 & 84 & 79 & 76 & 85 & 68 & 72 & 55 & 51 \\
\hline & $\mathrm{B}$ & 41 & 58 & 76 & 84 & 92 & 108 & 87 & 99 & 87 & 75 & 67 & 49 \\
\hline & $\mathrm{C}$ & 55 & 51 & 66 & 82 & 86 & 99 & 83 & 67 & 75 & 81 & 61 & 43 \\
\hline \multirow{3}{*}{ Stylonychia spp. } & $\mathrm{A}$ & 38 & 31 & 38 & 40 & 31 & 18 & 16 & 23 & 27 & 22 & 35 & 38 \\
\hline & $\mathrm{B}$ & 31 & 27 & 20 & 18 & 10 & 12 & 18 & 16 & 19 & 27 & 22 & 35 \\
\hline & $\mathrm{C}$ & 34 & 26 & 31 & 23 & 22 & 19 & 18 & 12 & 18 & 21 & 29 & 32 \\
\hline \multirow{3}{*}{ Vorticella spp. } & $\mathrm{A}$ & 28 & 21 & 23 & 17 & 12 & 15 & 10 & 19 & 22 & 16 & 21 & 25 \\
\hline & $\mathrm{B}$ & 33 & 25 & 18 & 12 & 09 & 05 & 07 & 12 & 10 & 15 & 15 & 18 \\
\hline & $\mathrm{C}$ & 29 & 32 & 21 & 19 & 09 & 11 & 10 & 15 & 16 & 21 & 18 & 19 \\
\hline \multirow{3}{*}{ Euglena } & $\mathrm{A}$ & 75 & 61 & 48 & 65 & 55 & 28 & 31 & 42 & 59 & 51 & 65 & 72 \\
\hline & $\mathrm{B}$ & 56 & 40 & 32 & 28 & 30 & 22 & 29 & 35 & 32 & 48 & 39 & 42 \\
\hline & $\mathrm{C}$ & 65 & 57 & 62 & 48 & 37 & 35 & 32 & 42 & 55 & 49 & 56 & 63 \\
\hline
\end{tabular}

\section{IV.Discussion}

Above data clearly indicates that the river has severe organic load and very high BOD values. The degree of pollution was found to be very high at the middle site B. This is mainly because the site is located near the centre of city and it receives three wide drains that bring excreta and garbage of entire city into the river water. Pollution load was also higher at site $\mathrm{C}$ as compared to site $\mathrm{A}$. This site is located near the industrial area and it receives two wide drains that pour the effluents of many saree printing industries and silver polishing plants. Seasonally, the pollution load was higher during summer (i.e., May, June and July) at all sites. This is because of presence of low amount of diluting water in the river (Hynes, 1978). So, the remaining water becomes highly concentrated with pollutants. Parameters like BOD and ammonia were found to be directly related with pollution load. When pollution load was high, the values of BOD were found to be very high. This is mainly because dissolved oxygen gets utilised in the oxidation of biological waste and also in the respiration of algae (Lieven Bervoets et al, 2005).

Ammonia is rapidly oxidised by certain microorganisms in natural water bodies from nitrite to nitrate, a process that requires the presence of dissolved oxygen. So, a high level of ammonia (sewage waste) can severely contribute to high BOD levels. High BOD levels and increased level of ammonia are indicators of heavy sewage (organic) pollution (Sharma et al, 1981). The values of phosphates and sulphates were also very high at site B compared to other two sites. Seasonally, the values were remarkably high during summers. These high values indicated a heavy organic load in the river during summers.

The Coliform population exhibited a positive trends with BOD, ammonia, chlorides and sulphates i.e., population was found very high, where pollution load was high. Therefore, highest population of these bacteria was recorded at Site B especially during summers. High level of Coliform again indicated the presence of heavy organic pollutants in the river (Agrawal et al, 2000). Coliform produce a bad and offensive smell in the water body. Coliform represented a negative trend with oxygen, probably because absence of oxygen leaves the waste untreated, which is favourable to the bacterial growth (Verma, Tyagi, Dalela, 1978). Spirogyra being an alga, exhibited a positive trend, mainly due to the accumulation of organic wastes (eutrophication). It exhibited a positive correlation with ammonia, chlorides and sulphates. High population of algae is the indicator of heavy pollution load in the water body (Klein, 1973). The population of Stylonychia, Vorticella and Euglena revealed a negative trend with BOD, ammonia, phosphates and sulphates. In summers, when the pollution load 
was high, a minimum population of these species was recorded. This clearly indicated that such organisms cannot survive in high BOD environment and organic enrichment. (Sharma et al, 1981). Ammonia is the excretory waste in Stylonychia and Vorticella. So these organisms cannot survive in a medium, which has high ammonical contents.

\section{V.Conclusion}

The study reveals that the sites selected for study are badly polluted by sewage and effluents of many small scale industries. Site B is the worst affected as it receives the maximum sewage load. Upstream and downstream sites have comparatively lesser pollution load. The populations of test organisms like Stylonychia, Vorticella and Euglena have shown severe fluctuation. The population count remains very low when the pollutant load is high. This does not indicate a healthy ecological balance in the river.

\section{References}

[1]. Agrawal P. K., Prabha S. (2000). Water quality of sewage drains entering river Yamuna at Mathura. J. Env. Biol. 21 (4), 375 -378.

[2]. APHA, (1989). Standard methods for the examination of water and waste water, 17th Ed. Washington D.C., U.S.A.

[3]. Bo Shi, Pete Lortscher, Doris Palfery (2012) Algal biomass anaerobic biodegradability. Journal of Applied phycology. 25(3): 757761. DOI: $10.1007 / \mathrm{s} 10811-012-9912-3$

[4]. Chojnacka K (2007) Bioaccumulation of Cr (III) ions by blue green alga Spirulina sp. Part 1. A comparison with biosorption. American journal of Agricultural and Biological Science. 2: 218-223.

[5]. Desouky Abdel-El- Haleem (2003) Acinetobacter, Environmental and biotechnological applications. African journal of Biotechnology. 2(4): 71-74.

[6]. Focht DD, Hurst CJ, Kundsen GR, Mclnernchy MJ, Stetzenback LD and Walter MV (1997) Aerobic biotransformation of polychlorinated biphenyls. Manual of Environmental Microbiology. ASM press, Washington DC. 811-814.

[7]. Gorbi G, Zanni C and Corradi MG (2007) Sulfur starvation and chromium tolerance in Scendesmus acutus, a possible link between metal tolerance and the regulation of sulfur uptake/ assimilation processes. Aqual Toxicol. 84(4): 457-464.

[8]. Hynes, H.B.N, (1978). The Biology of polluted waters, Liverpool University Press.; Liverpool, 200-204 pp.

[9]. Kalpan S, Eraso J and Roh JH (2005). Interacting regulatory networks in the facultative photosynthetic bacterium, Rhodobacter sphaeroides 2.4.1. Biochemical society Transaction. 33 (1): 51-55. DOI: 10.1042/BST0330051

[10]. Klein, L. (1973). River pollution, II-Causes and effect (5th Ed.), Butterworth and Co. Ltd.

[11]. Kliushnikova TM, Chernyshenko DV and Kasatkina TP (1992) The sulphate-reducing capacity of bacteria in the genus Pseudomonas. MikrobiolZh. 54(2): 49-54.

[12]. Lieven Bervoets, Guy Knaepkens, Marcel Eens and Ronny Blust (2005). Fish community responses to metal pollution . Environmental Pollution, Volume 138, Issue 2, Pages 191-376 (November 2005)

[13]. Megharaj M, Ramakrishnan B, Venkateswarlu K, Sethunathan N and Naidu R (2011) Bioremediation approaches for organic pollutants: a critical perspective. Environment International. 37(8): 1362-1375.

[14]. Sharma, K.D., N. Lal and P. D. Pathak, (1981). Water quality of sewage drains entering Yamuna at Agra. Ind. J. Env. Health., 23 (2), 118-122.

[15]. Tanya Kruitz and peter Wolk (1995) Use of filamentous cyanobacteria for Biodegradation of organic pollutants. Applied and Environmental microbiology 61(1): 234-238.

[16]. Verma S. R., A. K. Tyagi and R.C. Dalela, (1978). Physico-chemical and biological characteristics of Khadarabad drain in U.P. Ind. J. Env. H1th., 20 (1), 1-13.

[17]. WHO, (1984). International standards for drinking water, Third Ed. Geneva. 